\title{
Diphenylhydantoin Binding to Proteins in Plasma and Its Dependence on Free Fatty Acid and Bilirubin Concentration in Dogs and Newborn Infants
}

\author{
BERTIL B. FREDHOLM, ANDERS RANE, (28) AND BENGT PERSSON \\ Departments of Pharmacology, Clinical Pharmacology, Huddinge Hospital, and Pediatrics, St. Göran's Hospital, \\ Karolinska Institutet, Stockholm, Sweden
}

\section{Extract}

The binding of diphenylhydantoin (DPH) to plasma proteins was studied with an equilibrium dialysis method in plasmas in which concentrations of free fatty acids (FFA) were varied by physiologic means. In blood-perfused dog subcutaneous adipose tissue, sympathetic nerve stimulation caused an increase in plasma FFA concentration from control values of $0.26-0.58 \mathrm{mM}$ to peak levels of 0.63 to $3.44 \mathrm{mM}$. There was a linear relation between the binding of DPH and the FFA concentration in plasma from the same dog. When rat epididymal adipose tissue was incubated in dog plasma containing DPH, DPH protein binding decreased and tissue binding of the drug increased with increasing lipolytic rate. In plasma from 42 newborn infants the degree of DPH binding was significantly related to the albumin concentration as well as the bilirubin to albumin and FFA to albumin concentration ratios.

\section{Speculation}

Our data indicate that physiologically occurring variations in plasma FFA concentration can alter the plasma protein binding of drugs. We propose that such displacement will be quantitatively most important in blood perfusing adipose tissue during lipolysis and that the effect might lead to a preferential distribution of the drug to fat tissue during lipolysis.

Several drugs including DPH are bound to plasma proteins, mainly albumin, in newborn infants as well as in adults (12, 16). The degree of binding, and hence proportion of the drug that is biologically available, is influenced by numerous factors: the presence of other drugs and other organic molecules such as bilirubin, and the albumin concentration $(12,16)$. Serum albumin is also the major transport vehicle for FFA, the concentration of which is subject to large physiologic variations, especially during the neonatal period. Several reports have indicated that the addition of increasing concentrations of FFA in vitro decreases the binding of various organic ligands, including several drugs, to the albumin molecule $(17,19)$. There is, however, limited information concerning the role of physiologic variations of FFA on drug binding to albumin.

In order to evaluate the possible clinical significance of physiologic variations in plasma FFA levels on the degree of DPH binding we have examined the correlation between these variables in a group of newborn infants. In animal experiments we have also studied the effect on DPH protein binding of a rise in plasma FFA induced by sympathetic nerve stimulation of the perfused canine subcutaneous adipose tissue (4) and also the relation between DPH accumulation in adipose tissue and the degree of binding of the drug to plasma proteins. The results from the animal experiments suggest that local elevations of FFA might influence DPH binding and distribution. Similarly, the analysis of the clinical material indicated that FFA concentration variations might be one of the factors that determine overall drug binding.

\section{METHODS}

\section{IN SITU PERFUSED DOG ADIPOSE TISSUE}

Dogs were anaesthetized with sudium pentobarbital (30 $\mathrm{mg} / \mathrm{kg}$ ) and tracheostomized. Inguinal adipose tissue was isolated as described elsewhere (4). The nerve to the tissue was stimulated electrically ( $4 \mathrm{~Hz}, 12 \mathrm{~V}, 2 \mathrm{msec}$ for 30-60 min). The venous outflow was collected in ice-cooled centrifuge tubes and the blood cells were removed by centrifugation. The plasma was subsequently analyzed for FFA content (22) and DPH binding as described below.

\section{IN VITRO EXPERIMENTS}

Male Sprague-Dawley rats $(190-220 \mathrm{~g})$ were killed by a blow on the neck. The epididymal fat pads were removed and blotted on filter paper and weighed. The tissues, were incubated in 10 volumes of undiluted or diluted (1:3 in Krebs-Ringer bicarbonate buffer, $\mathrm{pH}$ 7.4) dog plasma in the presence of 15 or $45 \mu \mathrm{g} / \mathrm{ml}$ DPH containing trace amounts of $\left[{ }^{14} \mathrm{C}\right] \mathrm{DPH}$. After incubations for $1 \mathrm{hr}$, tissue was separated from plasma by filtration. The concentrations of glycerol (9) and FFA (22) and $\left[{ }^{14} \mathrm{C}\right] \mathrm{DPH}$ in the tissue and incubation medium as well as the degree of protein binding of DPH were determined. The tissues were homogenized in $5 \mathrm{ml}$ toluene, 1 $\mathrm{ml}$ of which was counted in a liquid scintillation spectrometer (23).

\section{NEWBORN INFANTS}

A total of 42 newborn infants was studied. Clinical data on these infants are given in Table 1. All infants except one were 
Table 1. Clinical data on infants and plasma concentrations of free fatty acids (FFA), bilirubin, albumin, and protein binding of diphenylhydantoin (DPH) determined on cord blood (cases 1-21) and on peripheral venous blood (cases 22-42)

\begin{tabular}{|c|c|c|c|c|c|c|c|c|}
\hline Case & Sex & Birth wt, g & $\begin{array}{c}\text { Birth length, } \\
\mathrm{cm}\end{array}$ & $\begin{array}{c}\text { Gestational age, } \\
\text { days }\end{array}$ & $\mathrm{FFA}, \mathrm{mM}$ & $\begin{array}{l}\text { Bilirubin, } \\
\mathrm{mg} / 100 \mathrm{ml}\end{array}$ & $\begin{array}{l}\text { Albumin, } \\
\mathrm{g} / 100 \mathrm{ml}\end{array}$ & $\begin{array}{l}\text { DPH binding, } \\
\% \text { unbound }\end{array}$ \\
\hline 1 & $\mathrm{~m}$ & 3,830 & 52 & 276 & 0.51 & 2.0 & 3.9 & 18.4 \\
\hline 2 & $\mathrm{~m}$ & 3,730 & 53 & 286 & 0.22 & 1.7 & 3.6 & 17.6 \\
\hline 3 & $\mathrm{f}$ & 3,190 & 50 & 290 & 0.21 & 0.5 & 3.2 & 15.4 \\
\hline 4 & $m$ & 5,100 & 55 & & 0.26 & 1.5 & 3.1 & 18.6 \\
\hline 5 & f & 3,360 & 50 & 276 & 0.23 & 2.0 & 3.0 & 17.7 \\
\hline 6 & $\mathrm{f}$ & 3,360 & 52 & 274 & 0.24 & 5.6 & 3.0 & 19.4 \\
\hline 7 & $\mathrm{f}$ & 3,350 & 52 & 288 & 0.30 & 2.0 & 3.3 & 15.3 \\
\hline 8 & $\mathrm{f}$ & 3,420 & 52 & 284 & 0.24 & $\begin{array}{l}2.0 \\
1.0\end{array}$ & 3.9 & 14.0 \\
\hline 9 & $\mathrm{f}$ & 3,630 & 54 & 293 & 0.32 & 1.3 & 4.7 & 14.0 \\
\hline 10 & $\mathrm{~m}$ & 3,070 & 50 & 271 & 0.40 & 1.5 & 3.8 & 16.4 \\
\hline 11 & $\mathrm{~m}$ & 4,520 & 54 & 291 & 0.34 & 1.5 & 3.7 & 16.4 \\
\hline 12 & $\mathrm{~m}$ & 2,930 & 49 & 282 & 0.33 & 1.5 & 3.4 & 16.2 \\
\hline 13 & $\mathrm{~m}$ & 2,490 & 48 & 270 & 0.34 & 1.5 & 3.4 & 17.5 \\
\hline 14 & f & 3,140 & 50 & 291 & 0.41 & 1.7 & 3.4 & 17.5 \\
\hline 15 & f & 2,860 & 48 & 280 & 0.28 & 1.5 & 3.1 & 17.4 \\
\hline 16 & $\mathrm{f}$ & 3,520 & 49 & 282 & 0.40 & 1.7 & 4.2 & 15.6 \\
\hline 17 & $\mathrm{f}$ & 3,470 & 50 & 271 & 0.42 & 2.0 & 4.2 & 17.2 \\
\hline 18 & $\mathrm{~m}$ & 4,000 & 53 & 285 & 0.32 & 1.7 & 3.6 & \\
\hline 19 & $\mathrm{~m}$ & 4,100 & 54 & 280 & 0.44 & 2.9 & 4.0 & 16.9 \\
\hline 20 & $\mathrm{~m}$ & 3,360 & 52 & 277 & 0.36 & 1.7 & 3.8 & 19.2 \\
\hline 21 & $\mathrm{~m}$ & 3,550 & 52 & 273 & 0.41 & 1.5 & 3.9 & 15.9 \\
\hline 22 & $\mathrm{~m}$ & 3,410 & 49 & 282 & 1.19 & 16.8 & 3.6 & 21.8 \\
\hline 23 & f & 3,060 & 48 & 290 & 1.02 & 1.0 & 3.4 & 17.2 \\
\hline 24 & f & 2,200 & 44 & 276 & 0.29 & 9.8 & 3.15 & 19.5 \\
\hline 25 & f & 3,460 & 49 & 286 & 1.32 & 9.8 & 3.6 & 19.4 \\
\hline 26 & f & 3,640 & 50 & 293 & 1.22 & 12.9 & 3.7 & 23.5 \\
\hline 27 & f & 3,750 & 53 & 299 & 1.44 & 5.3 & 3.6 & 16.1 \\
\hline 28 & $\mathrm{~m}$ & 3,280 & 51 & 288 & 0.78 & 5.8 & 3.5 & 16.9 \\
\hline 29 & f & 3,550 & 51 & 270 & 0.35 & 13.4 & 3.5 & 18.0 \\
\hline 30 & $\mathrm{f}$ & 3,120 & 49 & 280 & 0.57 & 14.4 & 3.8 & 18.1 \\
\hline \multirow[t]{3}{*}{31} & $\mathrm{~m}$ & 4,630 & 52 & 271 & 1.04 & 4.4 & 2.9 & 20.1 \\
\hline & & & & & 1.16 & 4.4 & 3.0 & 19.6 \\
\hline & & & & & 0.50 & 9.6 & 2.9 & 18.9 \\
\hline 32 & $\mathrm{~m}$ & 3,420 & 50 & 280 & 1.28 & 6.0 & 4.0 & 19.9 \\
\hline 33 & $\mathrm{f}$ & 3,180 & 50 & 288 & 0.26 & 3.6 & 2.6 & 17.9 \\
\hline 34 & $\mathrm{~m}$ & 4,130 & 54 & 291 & 0.81 & 3.2 & 3.7 & 15.2 \\
\hline 35 & $\mathrm{f}$ & 3,780 & 49 & 266 & 0.52 & 18.0 & 3.0 & 21.0 \\
\hline 36 & $\mathrm{~m}$ & 3,380 & 51 & 291 & 0.52 & 6.0 & 3.0 & 22.6 \\
\hline 37 & $\mathrm{f}$ & 2,090 & 45 & 245 & 0.51 & 12.0 & 2.3 & \\
\hline 38 & $\mathrm{~m}$ & 3,120 & 49 & 259 & 0.48 & 6.7 & 3.0 & 20.3 \\
\hline 39 & $\mathrm{~m}$ & 2,930 & 50 & 266 & 1.42 & 2.4 & 3.2 & \\
\hline 40 & $\mathrm{~m}$ & 2,950 & 47 & 252 & 0.55 & 13.9 & 2.9 & 18.1 \\
\hline 41 & $\mathrm{f}$ & 3,560 & 53 & 291 & 0.63 & 6.0 & 3.1 & 14.8 \\
\hline \multirow[t]{2}{*}{42} & $\mathrm{~m}$ & 4,270 & 55 & 287 & 0.42 & 2.0 & 3.6 & 17.9 \\
\hline & & & & & 0.81 & 7.2 & 3.1 & 18.4 \\
\hline
\end{tabular}

born at term; 37 had a normal birth weight, 3 were overweight, and 2 were underweight according to gestational age and sex (21). Cord blood was obtained from 21 infants, all of whom had an uneventful neonatal period. Blood was taken into heparinized tubes from the maternal end of the cord immediately after birth and before the placenta was delivered. The remaining 21 infants were observed or treated in the pediatric department for different reasons: maternal diabetes, prenatal asphyxia, hyperbilirubinemia, hypoglycemia, feeding problems, neonatal infections. In these cases venous blood was obtained at different times during the first week after birth in connection with sampling for diagnostic purposes. Blood was drawn from a cubital vein into a heparinized syringe. All samples were kept at $4^{\circ}$; plasma was separated by centrifugation within 15 min after sampling and was protected from light until analysis the following day.

Plasma concentrations of FFA (10), bilirubin $(6,13)$, albumin (from total protein determination by refractometry and separation of protein fractions on cellulose acetate by microzone electrophoresis (24)), and protein binding of DPH (as described below) were determined in duplicate.

\section{ASSAY OF PROTEIN BINDING}

Protein binding of DPH was studied with an equilibrium dialysis method (3) using cells of Lucite, divided into two equal compartments by a cellophane membrane. Only $0.5 \mathrm{ml}$ plasma is required in this method. ${ }^{14} \mathrm{C}$-labeled DPH (specific activity approximately $5 \mathrm{mCi} / \mathrm{mM}(25)$ ) was diluted with unlabeled DPH $(1: 4)$ and added to the plasma sample on one side of the membrane at a total concentration of $15 \mu \mathrm{g} / \mathrm{ml}$. Equilibrium with the other side of the membrane, containing a sodium phosphate buffer, $\mathrm{pH} 7.38$, was achieved after $6 \mathrm{hr}$ of incubation at $37^{\circ}$. The unbound fraction of the drug was determined from the ratio of radioactivity between the buffer and plasma phases. Radioactivity was measured in a Packard 
Tri-Carb using Instagel as scintillation medium. Quenching by bilirubin was corrected for by automatic external standardization.

\section{RESULTS}

The stimulation of the sympathetic nerve to inguinal adipose tissue led to an increase in the venous plasma FFA concentration from resting values ranging from $0.26-0.58$ $\mathrm{mM}$. The peak venous concentration in six dogs ranged between 0.63 and $3.44 \mathrm{mM}$. In Figure 1 the experimental results from two experiments in which peak concentrations above $3 \mathrm{mM}$ FFA were obtained is shown. It can be seen that there is a linear relationship between the concentration of FFA and the unbound DPH. In other experiments we found that over the concentration range $1-45 \mu \mathrm{g} / \mathrm{ml}$, the degree of protein binding was affected to approximately the same degree by increasing FFA concentrations.

Results from an in vitro experiment are shown in Table 2. Noradrenaline (NA) $(1 \mu \mathrm{M})$ increased lipolysis and the medium FFA concentration. At the same time the distribution of $\left[{ }^{14} \mathrm{C}\right] \mathrm{DPH}$ added to the incubation medium was bound less to proteins and more to the tissue. NA per se had no effect on plasma protein binding. Results from the same experiment are plotted in Figure 2 to demonstrate the linear relation between the association of the drug with tissue and the relative proportion of unbound drug. The points in the figure represent incubations in the presence or in the absence of NA, which suggests that the effect of NA on tissue binding is due to changes in the plasma protein binding of the drug. Moreover, the results indicate that the affinity of DPH for adipose tissue is approximately 3 times higher than that for the plasma water phase.

\section{NEWBORN INFANTS}

The individual concentrations of FFA, bilirubin, albumin, as well as the binding of DPH in vitro, expressed as percentage of unbound drug, are given in Table 1. We formed the FFA to albumin and bilirubin to albumin ratios, inasmuch as these variables are more meaningful in an analysis of drug binding than the absolute concentrations of FFA and bilirubin. The

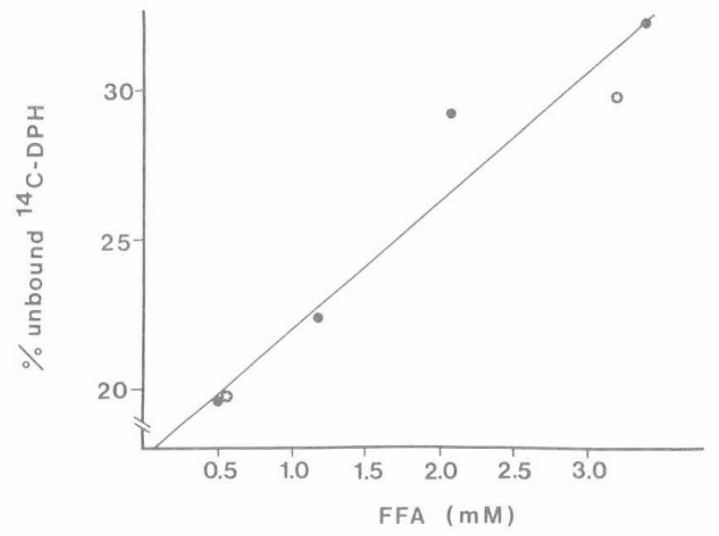

Fig. 1. Relation between free fatty acids $(F F A)$ concentration and protein binding of diphenylhydantoin in dog plasma. Dog $1($ ) $10 \mathrm{~kg}$, hematocrit 44.5 , adipose tissue weight $31.0 \mathrm{~g}$, hlood flow $8.71 \mathrm{ml} \times$ $\min ^{-1} \times 100 \mathrm{~g}^{-1} ; \operatorname{dog} 2(\bullet) 8 \mathrm{~kg}$, hematocrit 44.5 , adipose tissue weight $32.0 \mathrm{~g}$, blood flow $7.76 \mathrm{ml} \times \mathrm{min}^{-1} \times 100 \mathrm{~g}^{-1}$. The tissue was prepared as described in Methods. Venous plasma was sampled during resting conditions and pooled. The sympathetic nerve was stimulated with 4 $\mathrm{Hz}, 12 \mathrm{~V}, 2 \mathrm{msec}$ for $1 \mathrm{hr}$ or more. Venous samples were sampled continuously. Pooled samples were used for the determination of plasma protein binding of diphenylhydantoin at a concentration of 15 $\mu \mathrm{g} / \mathrm{ml}$.
Table 2. Effect of noradrenaline on lipolysis (glycerol release) and medium free fatty acids (FFA) concentration on distribution of diphenylhydantoin (DPH) between canine adipose tissue and proteins ${ }^{1}$

\begin{tabular}{lcccc}
\hline & $\begin{array}{c}\text { Lipolysis, } \\
\mu \mathrm{mol} \mathrm{g} \mathrm{g}^{-1} \\
\times \mathrm{hr}^{-1}\end{array}$ & $\begin{array}{c}\text { FFA conc., } \\
\mathrm{mM}\end{array}$ & $\begin{array}{c}\text { DPH, } \\
\% \text { in tissue }\end{array}$ & $\%$ Unbound \\
\hline No additions & $3.47 \pm 0.90$ & $3.50 \pm 0.32$ & $7.08 \pm 0.27$ & $24.94 \pm 0.29$ \\
Noradrenaline, & $10.86 \pm 1.63$ & $4.79 \pm 0.25$ & $8.57 \pm 0.26$ & $28.02 \pm 0.56$ \\
$\quad 10^{-6} \mathrm{M}$ & & & & \\
Difference & 7.39 & 1.29 & 1.49 & 3.08 \\
& $P<0.01$ & $P<0.05$ & $P<0.01$ & $P<0.01$ \\
\hline
\end{tabular}

${ }^{1}$ For experimental details see Methods. Mean values \pm SE are given.

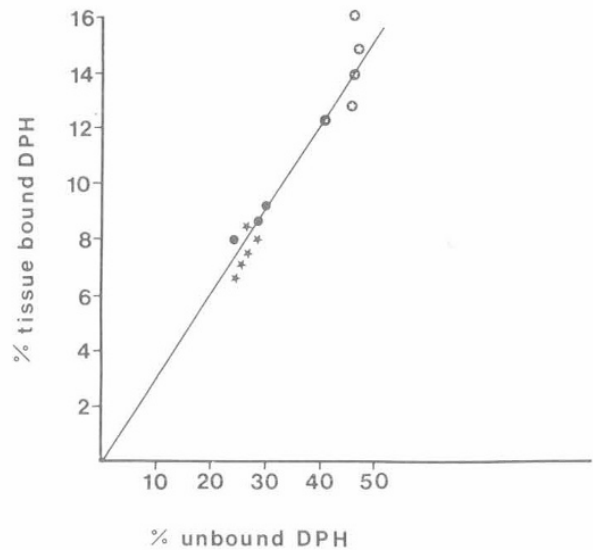

Fig. 2. Relation between the concentration of diphenylhydantoin $(\mathrm{DPH})$ in adipose tissue and the unbound concentration of DPH in incubation medium in percentage of total added DPH. Canine subcutaneous adipose tissue $(0.51-0.78 \mathrm{~g})$ was incubated as described in Methods. The line $(\mathrm{y}=0.3 \mathrm{X})$ is the line of identity for a 3 times higher affinity of the drug in adipose tissue than in plasma water, inasmuch as tissues were incubated in 10 volumes of medium. $\bullet: 45 \mu \mathrm{g}$ $\mathrm{DPH} / \mathrm{ml}$ undiluted plasma, $: 15 \mu \mathrm{g} \mathrm{DPH} / \mathrm{ml}$ undiluted plasma, $\star: 15$ $\mu \mathrm{g} \mathrm{DPH} / \mathrm{ml}$ plasma, diluted 1:3 with Krebs-Ringer bicarbonate buffer (mean of duplicate determinations).

mutual relation between these variables was determined by the correlation coefficient. Both the ordinary correlation coefficient, assuming a bivariate normal distribution, and the partial correlation coefficient, assuming a multivariate normal distribution, are given in Table 3. Plasma protein binding correlated best with the bilirubin to albumin concentration, but the relations to FFA to albumin and the albumin concentration were also significant.

\section{DISCUSSION}

In a detailed study on drug binding to human serum albumin, Rudman et al. (17) showed that FFA decrease the binding of several drugs such as salicylic acid, phenylbutazone, bishydroxycoumarin, and DPH. From kinetic analyses the authors concluded that besides displacement, other factors such as conformational changes of the albumin molecule might be responsible for this effect of FFA. These authors also studied the drug binding in rabbit sera, in which the FFA concentration was elevated by ACTH. They found a significantly decreased binding at $2.2-3.0 \mathrm{mM}$ FFA.

We have increased the plasma FFA concentrations in the dog in a physiologic manner by stimulation of sympathetic nerves to the isolated perfused canine adipose tissue. It should be pointed out that nerve stimulation of the blood perfused adipose tissue causes little or no change in the plasma albumin 
Table 3. Correlations between albumin concentration (I), free fatty acids to albumin concentration ratio (II), bilirubin to albumin concentration ratio (III), and the percentage of unbound $\left[{ }^{14} \mathrm{C}\right]$ diphenylhydantoin in plasmas from newborn infants $(I V)^{1}$

\begin{tabular}{lcc} 
& $\begin{array}{c}\text { Correlation } \\
\text { coefficients }\end{array}$ & $\begin{array}{c}\text { Partial correlation } \\
\text { coefficients }\end{array}$ \\
\hline r I, II & -0.1490 & -0.0859 \\
r I, III & $-0.3835^{2}$ & -0.2629 \\
r I, IV & $-0.3904^{2}$ & $-0.3190^{3}$ \\
r II, III & $0.3088^{3}$ & 0.1238 \\
r II, IV & $0.3958^{2}$ & $0.3828^{2}$ \\
r III, IV & $0.5615^{2}$ & $0.5894^{2}$
\end{tabular}

${ }^{1}$ Data are from Table 1. Correlation coefficients and partial correlations were calculated according to the procedure of Snedecor and Cochran (18).

${ }^{2} P<0.01$.

${ }^{3} P<0.05$.

concentration (11). Consequently, we can expect that the change in FFA concentration under these circumstances is directly proportional to a change in FFA to albumin concentration ratio. The binding of DPH decreases with increasing FFA plasma concentration (Fig. 1), in agreement with the results of Rudman et al. (17).

Similarly, the unbound fraction of DPH increased when the plasma FFA concentration was increased by lipolysis in vitro (Table 2). This finding is significant in view of the linear relation between the percentage of unbound $\mathrm{DPH}$ and the accumulation of the drug in the tissue under the same circumstances. When taken together, these results suggest that lipolysis, by causing an increased release of FFA, can decrease the binding of drugs to plasma proteins and hence the accumulation of drugs in fat. This mechanism might explain the results of Kniewald et al. $(7,8)$ which show an increased tissue binding of phenobarbital and DPH in fat during lipolytic conditions, whether induced in vivo by starvation or in vitro by the addition of lipolytic agents.

In the immediate neonatal period there are large variations in FFA both within and between individuals (15). The above findings suggested that newborn infants might exhibit considerable differences in the degree of DPH binding caused by such variations in FFA. In these infants there are also considerable differences in bilirubin concentration. In a previous study it was shown that hyperbilirubinemic children bind significantly less DPH than normal (16). However, the plasma FFA concentrations were not investigated in that study. It was therefore considered to be of interest to evaluate the importance of both FFA and bilirubin on the plasma protein binding.

When considered in isolation, by the use of partial correlation analysis, both of these factors, as well as the concentration of albumin, were found to correlate significantly with the degree of DPH binding. Our results have thus shown that physiologically occurring variations in FFA can influence the degree of drug binding in newborn infants as well as in experimental animals.

The displacement of drugs from plasma proteins may alter the therapeutic effect, although the clinical importance of the phenomenon often has been overemphasized. If the drug distributes in the total body water, it can be calculated that displacement from protein binding sites would produce a clinically important increase in the unbound fraction only if the drug binding were greater than $90 \%$. DPH has a relatively large volume of distribution (approximately 0.6 liters $/ \mathrm{kg}$ body wt (14) and in the present study we found less than $90 \%$ binding of the drug. It must be concluded that it is unlikely that the observed displacement of DPH by FFA is of major clinical significance. For other drugs the effect might be of greater importance, especially if the FFA concentration reaches very high values. The results of Rudman et al. (17) and of Starinsky and Shafrir (20) similarly suggest that only extreme FFA concentrations significantly alter drug and bilirubin binding to serum albumin.

Such very high concentrations of FFA are likely to occur primarily in the blood perfusing adipose tissue during lipolysis. Thus one might speculate that FFA could play a more localized role by decreasing drug binding to plasma proteins in blood perfusing fat tissue. This could lead to a preferential distribution of drug to organs displaying a high rate of lipolysis. The results of Kniewald et al. $(7,8)$ are certainly compatible with this hypothesis.

\section{SUMMARY}

It has been shown that increasing the concentration of FFA in plasma by lipolysis, either in perfused dog subcutaneous adipose tissue or rat epididymal adipose tissue, leads to a decreased DPH binding to plasma proteins. Furthermore, such an increase in the concentration of free drug is associated with an increased accumulation of drug in fat tissue. In plasma from newborn infants, DPH binding was found to correlate with the albumin concentration, the bilirubin to albumin, and the FFA to albumin concentration ratios.

\section{REFERENCES AND NOTES}

1. Borgå, O.: Personal communication.

2. Dole, V. P.: A relation between non-esterified fatty acids in plasma and the metabolism of glucose. J. Clin. Invest., 35: 150 (1956).

3. Ehrnebo, M., Agurell, S., Jalling, B., and Boreus, L. O.: Age differences in drug binding to plasma proteins: Studies on human foetuses, neonates and adults. Eur. J. Clin. Pharmacol., 3: 189 (1971).

4. Fredholm, B. B.: Studies on the sympathetic regulation of circulation and metabolism in isolated canine subcutaneous adipose tissue. Acta Physiol. Scand., 80 (suppl. 354): 1 (1970).

5. Gordon, R. S., Jr., and Cherkes, A.: Unesterified fatty acids in human blood plasma. J. Clin. Invest., 35: 206 (1956).

6. Jendrassik, L., and Gróf, P.: Vereinfachte photometrische Methode zur Bestimmung des Blutbilirubins. Biochem. Z., 297: 293 (1938).

7. Kniewald, J., Bizzi, A., and Garattini, S.: Relationship between lipolysis and storage of phenobarbital in adipose tissue. Eur. J. Pharmacol., 17: 186 (1972).

8. Kneiwald, J., Bizzi, A., and Garattini, S.: Relationship between lipolysis and storage of diphenylhydantoin in adipose tissue. Experientia, 28: 628 (1972).

9. Laurell, S., and Tibbling, G.: An enzymatic fluorimetric micromethod for determination of glycerol. Clin. Chim. Acta, 13: 317 (1966).

10. Laurell, S., and Tibbling, G.: Colorimetric microdetermination of free fatty acids in plasma. Clin. Chim. Acta, 16: 57, 1967.

11. Linde, B.: Personal communication.

12. Lunde, P. K. M., Rane, A., Yaffe, S. J., Lund, L., and Sjöqvist, F.: Plasma protein binding of diphenylhydantoin in man: Interaction with other drugs and the effect of temperature and plasma dilution. Clin. Pharmacol. Ther., 11: 846 (1970).

13. Nosslin, B.: The direct diazo reaction of bile pigments in serum. Scand. J. Clin. Lab. Invest., 12: Suppl. 49 (1960).

14. Odar-Cederlöf, J., and Borgå, O.: Kinetics of diphenylhydantoin in uraemic patients: Consequences of decreased plasma protein binding. Eur. J. Clin. Pharmacol., 7: 31 (1974).

15. Persson, B., and Gentz, J.: The pattern of blood lipids, glycerol and ketone bodies during the neonatal period, infancy and childhood. Acta Paediat. Scand., 55: 353, 1966.

16. Rane, A., Lunde, P. K. M., Jalling, B., Yaffe, S. J., and Sjöqvist, F.: Plasma protein binding of diphenylhydantoin in normal and hy perbilirubinemic infants. J. Pediat., 78: 877, 1971.

17. Rudman, D., Bixler, J., and DelRio, A. E.: Effect of free fatty acids on binding of drugs by bovine serum albumin, by human serum albumin and by rabbit serum. J. Pharmacol. Exp. Ther., 176: 261 (1971).

18. Snedecor, G. W., and Cochran, W. G.: Statistical Methods, Ed. 6 (Iowa State University Press, Ames, Iowa, 1967).

19. Spector, A. A., and Imig, B.: Effect of free fatty acid concentration on the transport and utilization of other albuminbound compounds: Hydroxyphenylazobenzoic acid. Mol. Pharmacol., 7: 511 (1971). 
20. Starinsky, R., and Shafrir, E.: Displacement of albumin-bound bilirubin by free fatty acids: Implications for neonatal hyperbilirubinemia. Clin. Chim. Acta, 29: 311 (1970).

21. Sterky, G.: Swedish standard curves for intrauterine growth. Pediatrics, 46: 7 (1970).

22. Trout, D. L., Estes, E. M., Jr., and Friedberg, S. J.: Titration of free fatty acids of plasma: a study of current methods and a new modification. J. Lipid Res., 1: 199 (1960).

23. Packard Tri-Carb, Packard Instrument Co., Downer's Grove, Ill.

24. Beckman Instruments, Palo Alto, Calif.

25. New England Nuclear Corp., Boston, Mass.

26. This study was partially supported by a grant from Föreningen

Copyright (c) 1975 International Pediatric Research Foundation, Inc.
Margarethahemmet, Semper Fund for Nutritional Research, the Swedish Medical Research Council (40X-2553, 40P-3828, 19X3787, 19P-4106, 04X-4496), “Expressen's" Prenatal Research Fund, and the Association of the Swedish Pharmaceutical Industry.

27. Miss Margareta Stensdotter, and Miss Gerd Lundqvist provided technical assistance.

28. Requests for reprints should be addressed to: Anders Rane, M.D., Department of Clinical Pharmacology, Karolinska Institutet, Huddinge Hospital, Flemingsbergsgatan, S-141 86, Huddinge, Stockholm, Sweden.

29. Accepted for publication July 26, 1974.

Printed in U.S.A.

Pediat. Res. 9: 30-34

Cellular replication

growth

mumps virus

\title{
The Biological and Biochemical Pathogenesis of Mumps Virus-induced Embryonic Growth Retardation
}

\author{
TERRY YAMAUCHI, ${ }^{(40)}$ JOSEPH W. ST. GEME, JR., WILLIAM OH, AND CATHERINE W. C. DAVIS
}

Department of Pediatrics, Harbor General Hospital, UCLA School of Medicine, Torrance, California, USA

\section{Extract}

Embryonic mumps virus infection in the avian host leads to fetal growth retardation. The mechanism of this retardation has not been established.

The avian host is unique in that the direct effect of a virus on the embryo may be ascertained in the absence of a placenta.

Using radioisotope labeling techniques, DNA, RNA, and protein metabolism was investigated in tissues from infected and control chickens. Metabolism in organ tissue cultivated in vitro and then infected was also studied using the same radioisotope techniques.

At hatch, the mean body weight of eight experimental chickens infected with mumps virus early during embryonic incubation was significantly less than that of 19 controls. This lower weight was evident in the brain of the infected chickens. The brain and carcass contained decreased amounts of RNA and protein when compared with uninfected control chickens. The kidney was the only other organ in which the protein content in experimental chickens was less than in controls.

There was no difference in the DNA content of organs from in ovo-infected and control chickens or organ tissues cultivated in vitro before infection with mumps virus. Similarly, measurements of cell number at the same time were equal.

Viral assay of the chickens infected in ovo revealed highest titers of virus in the heart throughout the last half of incubation. Intermediate titers of virus were recovered from the lung, spleen, and skeletal muscle. Low quantities of virus were recovered from the brain and liver. The bursa contained high titers of virus at midincubation but these titers rapidly declined by hatch.
Growth retardation in the mumps virus-infected chicken model is not due to a reduction in cell number but appears to be caused by a diminution in cell size.

\section{Speculation}

The relation between embryonic mumps virus infection and myocarditis is supported by the findings of high titers of virus throughout the incubation period. It is postulated that altered cardiac function results in a state of hypofusion and a preferential effect is seen in the brain with consequent diminution of cell size rather than cell number.

Embryonic growth retardation has been attributed to many factors, including metabolic defects (10), malnutrition of fetal and maternal origin $(20,24,25,32)$, congenital anomalies ( 3 , $21)$, and infection $(1,2,26)$. Under normal conditions the embryo grows as the population and size of cells increase. Conditions which impair either cellular variable will result in growth retardation. Several experimental models of fetal growth retardation in the mammal have been particularly illuminating. Wigglesworth (31) and Emmanouilides et al. (9) ligated the uterine and umbilical arteries of the rat and sheep, respectively, producing placental insufficiency which resulted in fetal growth retardation.

The avian model offers the opportunity for unique experimentation in that the direct effect of a virus on the chicken embryo may be ascertained in the absence of a placenta. Previous work has demonstrated that mumps virus infection during early embryonic life causes growth retardation of the embryo and newly hatched chicken (27). The 